\title{
Proposta de sequência didática a partir do filme Os vingadores: guerra infinita
}

\author{
Teaching sequence proposal from the film The Avengers: infinite war
}

\author{
(iD) Telma Temoteo dos Santos \\ Doutora em Ciências (Ensino em Biociências e Saúde) \\ pela Fundação Oswaldo Cruz (IOC-FIOCRUZ) \\ Docente na pós-graduação lato sensu em Ensino de Biociências e Saúde (IOC-FIOCRUZ) \\ Coordenadora Pedagógica e Docente de Biologia no Colégio Anglo Resende \\ temoteo.telma@gmail.com
}

Resumo: O objetivo deste artigo é divulgar uma sequência didática estruturada a partir do filme Os vingadores: guerra infinita, utilizado como produtor de temas geradores para a disciplina Biologia na educação básica. Partiu-se da motivação do vilão Thanos, que defende a destruição da metade dos seres vivos de todas as galáxias como solução para a escassez de recursos, superpopulações e violência. $O$ trabalho foi desenvolvido com base em Antoni Zabala que define epistemologicamente as sequências didáticas como meio articulador de atividades convergentes em objetivos de aprendizagem. O desenho metodológico compreendeu a análise do filme e pesquisas sobre os temas genética, evolução e biotecnologia. Esta pesquisa explora as potencialidades didáticas do filme como recurso de problematização inicial, sem a pretensão de discutir os pontos científicos corretos ou incorretos nele apresentados. Espera-se que as atividades descritas fomentem discussões metodológicas visando um ensino de ciências orientado para a interseção entre conhecimentos cotidianos e científicos.

Palavras-chave: Ensino de ciências. Ensino de biologia. Sequências didáticas. Filmes no ensino.

Abstract: The purpose of this article is to disseminate a didactic sequence structured from the film The avengers: infinite war, used as a producer of generating themes for the discipline Biology in basic education. It was based on the motivation of the villain Thanos, who defends the destruction of half of the living beings of all galaxies as a solution to the scarcity of resources, overpopulations and violence. The work was developed based on Antoni Zabala who epistemologically defines didactic sequences as a means of articulating activities converging on learning objectives. The methodological design included the analysis of the film and research on the topics of genetics, evolution and biotechnology. This research explores the didactic potentialities of the film as a resource for initial problematization, without the intention of discussing the correct or incorrect scientific points presented in it. It is hoped that the activities described will foster methodological discussions aimed at teaching science oriented towards the intersection between everyday and scientific knowledge.

Keywords: Science teaching. Biology teaching. Didactic sequences. Teaching films. 


\section{Introdução}

O avanço das ciências e o desenvolvimento de novas tecnologias promoveu o surgimento de modelos sociais como nunca antes vistos, ressignificando as formas como os sujeitos se relacionam, produzem e entendem o mundo. Ao mesmo tempo, a globalização trouxe avanços incontestáveis e promoveu a exclusão sistemática, pois além do não acesso igualitário às tecnologias e aos dados por elas disseminados, quando há, não se configura em posse de informações, muito menos, de conhecimento (CASTELLS, 2017; LIBÂNEO; OLIVEIRA; TOSCHI, 2012).

E, inevitavelmente, estas discussões estão em paralelo a como as escolas têm conduzido suas práticas de ensino de ciências (com raras exceções): de forma apática, mecânica, descontextualizada, submetidas às avalições externas, currículos mínimos e às restrições mercadológicas e neoliberais (DELIZOICOV; ANGOTTI; PERNAMBUCO, 2018).

“A escola, a sociedade e os estudantes mudaram!”. Afirmações similares são corriqueiras e fomentam debates nos conselhos de classe, nas reuniões pedagógicas e nos cursos de formação continuada. Essa constatação permeada ora por surpresa, incertezas e medo frente ao novo cenário, levanta o desafio imperativo de aproximar os saberes científicos dos saberes cotidianos e das vivências dos indivíduos.

Harres (2000, p. 38) pondera sobre o erro de enunciar a ciência como “(...) apartada de qualquer sentimento que não seja lógico, frio e racional”. E, ainda: dissociada de tudo que é considerado "comum". As representações sociais dos sujeitos são oriundas de processos experienciais não restritos ao ambiente escolar, com potencial nunca antes vivenciado com o advento da Internet e propulsão de discussões em fóruns, chats e redes sociais. Ainda assim a escola mantém-se dentro de uma "bolha", ao não reconhecer a validade desses discursos, e por não os considerar legítimos para adentrarem os currículos ou ainda as salas de aulas.

Para Cachapuz et al (2005) é necessária uma renovação do ensino de ciências: sendo inadmissível a apresentação das ciências como uma área restrita aos laboratórios de pesquisa; ela também emerge e se reestrutura da observação atenta dos elementos que constituem a realidade, ou seja, está em todo lugar. Caberá à escola aproveitar a curiosidade e a emoção natural dos estudantes para intensificar os debates na sala de aula e favorecer a aprendizagem interdisciplinar dos temas curriculares.

As salas de aulas podem ser locais de produção ativa de pensamento, se houver oportunidades para a expressão de ideias sobre o cotidiano, e com a mediação do professor a apropriação do discurso formal das ciências para a melhor compreensão, argumentação e debate. Sobre isso, enquanto Demo (2002) defende o desenvolvimento do ensino que conduza ao saber 
pensar, Carvalho (2016, p. 12) fala sobre "favorecer a vivência de propostas inovadoras e a reflexão crítica explícita das atividades de sala de aula”. Ou seja, o professor transmissor de conteúdos deve dar lugar ao sujeito que esteja disposto a "modificar suas ideias e atitudes de ensino." (CARVALHO, 2016, p. 10). Como produzir espaços dialógicos, interdisciplinares e motivadores para a aprendizagem?

Em primeiro lugar, com uma incursão pedagógica aos centros de interesse dos estudantes (temas geradores) por meio de atividades que contemplem a observação e formulação de perguntas. Se por um lado a participação dos estudantes não deve ser reduzida a expressão de meras opiniões ou posicionamentos desconexos, por outro lado, os momentos dialógicos propiciarão a construção de argumentos, embasados em estudos científicos históricos e atuais.

E, em adição, mediar o reconhecimento que os resultados das pesquisas científicas, presentes nos livros didáticos, não servem unicamente para a formação de cientistas, ou biólogos, físicos e químicos, no caso das ciências da natureza, mas, para que os sujeitos, independentemente de suas pretensões acadêmicas ou profissionais, possam fazer uso deles para compreender a dinâmica social, cultural e tecnológica dos seus tempos.

Assim, transporto essas considerações iniciais para o ensino, cujo destaque curricular tem sido a apresentação de uma linha do tempo linear e concisa, restrita às descobertas de alguns sujeitos históricos, com o objetivo de levar os estudantes a obterem êxito na resolução de exercícios e problemas. Ou seja, são as exigências dos vestibulares e Exame Nacional do Ensino Médio (ENEM) que determinam a prática pedagógica, não apenas nas Ciências da Natureza como em outras disciplinas.

Deste modo, este trabalho objetivou o desenvolvimento de uma sequência didática para o Ensino de Ciências, para os grandes temas da genética e evolução, a partir de um tema gerador do cotidiano dos estudantes. Para isso, foi utilizado o filme Os Vingadores: Guerra Infinita com sugestões de possíveis abordagens teóricas e metodológicas. Pretende-se conduzir estudantes e professores a refletirem sobre os locais e objetos que proporcionam um debate sobre as ciências, e a constatação de que a aprendizagem pode ocorrer por meio de diversos recursos, sejam cientificamente coerentes ou não.

O material desenvolvido pode ser readaptado e aplicado para turmas do ensino fundamental (ciências) e médio (biologia), bem como ser objeto de debate em cursos de formação inicial e continuada de professores. 


\section{Justificativa}

A escolha do filme Vingadores Guerra Infinita do estúdio Marvel, justifica-se por alguns pontos importantes: o seu lançamento foi aguardado pelos fãs em escala mundial, ao reunir as principais personagens já apresentadas em filmes solos. O filme bateu algumas marcas muito importantes, nos quesitos arrecadação no primeiro final de semana de estreia, público e arrecadação total.

No filme, o vilão Thanos busca as seis joias do infinito (espaço, realidade, poder, alma, mente e tempo) para compor a sua manopla, uma espécie de luva, e assim obter poder imensurável para alcançar os seus objetivos. O vilão justifica seus atos de extermínio em prol da justiça, equilíbrio e paz.

Entretanto, com o passar do tempo após a estreia do filme, extrapolando os comentários sobre o desenrolar das personagens e os eventos que iriam compor a segunda parte da estória (no filme Vingadores: Ultimato, lançado no ano seguinte), outras temáticas vieram à tona, dentre elas, o motivo do vilão: estaria ele, totalmente errado? A Terra, e outros habitats, suportariam o uso contínuo e a não renovação dos seus recursos?

Sobre a escolha pelo gênero fantasia, parto do imaginário fornecido para a construção e entendimento da realidade dos sujeitos envolvidos. A linguagem informal dos filmes diferente dos documentários, é um tipo de produção alinhada aos centros de interesse do público-alvo aumentando a possibilidade de adesão dos sujeitos (CASTILHO et al 2017). Ademais, esse tipo de filme promove o desencadeamento de elementos novos na aprendizagem que de outra forma não seriam identificados. Deste modo, a introdução deste recurso no ensino de ciências pode constituir uma alternativa didática viável, pois: i) pelo potencial de mobilizar diferentes sujeitos; ii) apresenta discurso com capacidade de difusão e, em parte, compreensível, e iii) enunciam uma linguagem acessível e, por isso, aproximam o público dos temas científicos pertencentes à física, química e a biologia (HARRES; SOUZA, 2008).

Todavia, seria possível relacionar o imaginário, as ações ficcionais e conhecimentos científicos, lançado mão de filmes que não tenham a pretensão por fornecer um debate "legítimo" sobre ciências? Os autores Piassi e Pietrocola (2009) alertam sobre as investigações didáticaspedagógicas que se ocupam em verificar os conceitos corretos e incorretos presentes nos filmes de ficção científica e deixam de lado o potencial criativo. Para alguns, filmes com cenas fantasiosas ou mesmo flagrantemente contrárias ao conhecimento científico seriam didaticamente menos relevantes do que os que trazem situações realistas. Entretanto, 
a ficção científica constitui por si só uma modalidade de discurso sobre a ciência na medida em que expressa, por meio do cinema e da literatura, interesses e preocupaçôes em torno de questões cientificas presentes que influem diretamente no âmbito sociocultural (PIASSI; PIETROCOLA, 2009, p. 525, grifo da autora).

É sobre esse “âmbito sociocultural” que Freire (1979;2011) é catedrático quando orienta práticas educativas a partir de elementos significativos das realidades dos sujeitos, pois para ele, só a partir da leitura do contexto e do reconhecimento da sua legitimidade, a ação do professor pode ser realizada. A análise do cotidiano é transpassada pelo olhar humilde do observador, o qual não se preocupa em colocar o certo e o errado em campos contraditórios, mas enxerga nas nuances das expressões dos elementos da sociedade oportunidades legítimas de discussão da ciência.

Assim, nos subtópicos seguintes, serão apresentados os referenciais teóricos que guiaram a discussão inicial e para a emersão do tema gerador deste trabalho.

\section{Fundamentação teórica}

\subsection{O ensino de ciências por meio das sequências didáticas e de conteúdos}

Quando a importância e a missão do Ensino de Ciências são reduzidas a formação estritamente acadêmica perde-se de vista o sentido da pluralidade de escolhas de projetos de vida dos sujeitos, e também desta área se apresentar como um meio de disseminação de uma ciência para todos. Portanto, quais seriam os objetivos e as finalidades da educação para além do ensino propedêutico e quais as habilidades, competências e visões de mundo se pretende desenvolver nos estudantes?

Em busca de resposta para essa e outras questões, autores como Pozo e Crespo (2009), Carvalho, Cachapuz e Gil-Pérez (2012), Delizoicov, Angotti e Pernambuco (2018) e Cachapuz et al (2005) apontam a necessidade permanente de questionar qual a função social do ensino de ciências e para quem se deseja ensinar ciências. Segundo esses autores, a educação deve ter a intencionalidade voltada para a aprendizagem (ação do estudante) e não somente para o ensino (ação do professor), pois apenas dessa maneira o estudante seria posto como norteador e agente propulsor de qualquer planejamento didático. Para Pozo e Crespo (2009), mais importante do que os conteúdos a serem ensinados são as habilidades desenvolvidas durante o percurso da aprendizagem. Ou seja, a prática pedagógica que consegue se desvencilhar das amarras metodológicas da apresentação de conteúdo e resolução de exercícios para fixar o ensino estará atenta para as demandas atuais de uma formação integral.

As duas questões apontadas pelos autores supracitados, por um lado, levam a reflexão sobre $\mathrm{o}$ (s) papel (is) da ciência, como uma ferramenta para os estudantes serem capacitados para saber o 
porquê, como faz̧er e para que faz̧er, suas ações cotidianas (POZO; CRESPO, 2009). Entender os sentidos das relações envolvidas em qualquer situação conduz ao aprimoramento das técnicas, a formulação de pensamentos complexos e ações significativas. Por outro lado, nos leva a defesa dos modelos múltiplos de educação os quais proporcionam aos estudantes a "apreciação global da ciência e da tecnologia." (CACHAPUZ et al, 2005 p.23).

Mas, por que ainda há resistência e até mesmo descrença na ciência, por parte dos sujeitos, independente de classe social? Em primeiro lugar, pelo lugar que a ciência ou os que produzem a colocam: pertencente apenas a uma elite intelectual, sem qualquer relação com os saberes ditos comuns. Em segundo, um ofício, realizada por “mentes brilhantes”, cujos perfis para alguns estão bem distantes das classes populares. E, em terceiro, para fazer ciência ou compreendê-la é necessário um tipo “especial” de educação, não ofertada em escolas destinadas às classes populares (MARTINS, 2006).

Razões pelas quais é importante que o conhecimento científico seja contextualizado, já que durante a formação escolar não se pretende afastar ou achar que possa haver uma aprendizagem deslocada da intepretação da realidade feita pelos sujeitos. É indiscutível, portanto, um ensino de Ciências que valorize a imaginação, seja motivador, inovador e atualizado.

Caberá, deste modo, aos professores, rearranjos nos planos de ensino para inserir eventos que captem a atenção dos estudantes, tais como filmes, jogos, música, exposições socioculturais, visita aos museus ou parques, a publicação de uma notícia, dentre outros. Muitas dessas situações são ricas em temas geradores para o ensino, porém, dada ao destaque metodológico concentrado nos livros, não são percebidas.

Formular os planos de ensino e de aulas a partir da escuta atenta em uma parceria com o currículo escolar é oportunizar alinhamentos positivos entre o professor e os estudantes. Consiste também na busca por conexões entre os discursos dos saberes ditos comuns com os saberes científicos e escolares e ações do cotidiano. Ou seja, uma ação do professor que empreende a prática de ensino em diferentes estratégias incluindo o espaço dialógico, com a valorização das expressões discursivas dos estudantes, voltada para o aprendizado integral.

Assim, cabe a definição de Zabala (1998), o qual apresenta as sequências didáticas como uma

(...) maneira de encadear e articular as diferentes atividades ao longo de uma unidade didática. (...) as sequências podem indicar a função que tem cada uma das atividades na construção do conhecimento ou da aprendizagem de diferentes conteúdos e, portanto, avaliar a pertinência ou não de cada uma delas, a falta de outras ou a ênfase que devemos lhe atribuir (ZABALA, 1998, p. 20). 
Ou seja, o estabelecimento das sequências didáticas na prática docente, pressupõe a existência de um planejamento no qual o recurso esteja inserido em um roteiro de ensino visando a aprendizagem de longo prazo e não apenas pontual.

Segundo Zabala (1998), não há um modelo ideal de sequência didática, pois depende dos objetivos de aprendizagem, das expertises do professor, das expectativas dos estudantes e do contexto educacional. Porém, para ele, há elementos que quando presentes nas sequências podem auxiliar o alcance do seu principal objetivo: promover a aprendizagem. Ele, elenca alguns, dentro da concepção construtivista:
a) valorização dos conhecimentos prévios dos estudantes;
b) verificação da significância e funcionalidades dos novos conteúdos;
c) nível de desenvolvimento;
d) zona de desenvolvimento proximal;
e) conflito cognitivo e atividade mental;
f) atitude favorável;
g) autoestima e autoconceito e;
h) aprender a aprender.

Ou seja, para aprender algo, o estudante precisa inserir o objeto de sua atenção em seu meio, traçar relações com o que já conhece e com o novo (oriundo de suas relações sociais dentro e fora da escola) e atribuir-lhe significados. É pela capacidade de interpretar a realidade e formar argumentos que os estudantes se tornam sujeitos sociais. Neste lugar, o professor é o mediador na complexa tarefa em guiar os estudantes, com suas experiências e saberes prévios para a compreensão das ciências, apresentadas nas disciplinas escolares.

\section{Caminho metodológico}

No início deste percurso é importante ressaltar que o caminho metodológico escolhido tem relação direta com as minhas percepções e vivência com os discentes, e levaram a identificação do tema gerador principal deste trabalho. Outros temas poderão ser identificados, já que o filme apresenta narrativas da Física, Química, Biologia, Artes e Humanidades.

Trata-se de uma pesquisa qualitativa (LÜDKE E ANDRÉ, 2013), de discussão teórica e de proposta de intervenção. Para a análise fílmica, elegeu-se a priori as discussões presentes em Penafria (2009) e a posteori em Siqueira (2017): na primeira autora, encontra-se uma breve discussão sobre a definição de análise de filmes e como fazê-la . Já na segunda, indica-se o caminho da análise 
SANTOS, Telma Temoteo dos. Proposta de sequência didática a partir do filme Os vingadores: guerra infinita

considerando o filme como um relato e, a partir daí, a análise de conteúdo, decompondo-o em partes.

Nesta pesquisa, acrescentou-se a essas orientações metodológicas as seguintes etapas: após a decomposição em partes do filme, buscou-se identificar as categorias estruturantes e os temas geradores associados a elas.

A partir da identificação do tema gerador (Figura 1), foi escolhido a metodologia de ensino e as atividades para estruturar a proposta didática. Como já apontado por Freire (1979, p. 18) o tema gerador é "[...] o pensamento do homem sobre a realidade e a sua ação sobre esta realidade que está em sua práxis”. Por isso, metodologias que colocam o estudante como o responsável por sua aprendizagem, como sujeito produtor de conhecimento, pautadas na concepção construtivista, são bem-vindas e podem auxiliar o professor no alcance de seus objetivos de ensino.

Figura 1 - Sequências de ações metodológicas para a construção da sequência didática para discussão dos temas geradores presentes no filme Os vingadores: guerra infinita

\begin{tabular}{|l|l|l|}
\hline 1. Tema Gerador & 2. Metodologia \\
\cline { 2 - 3 } $\begin{array}{l}\text { Identificado por meio de } \\
\text { ações dialógicas, escuta } \\
\text { atenta, leitura e imersão no } \\
\text { contexto dos indivíduos } \\
\text { participantes. }\end{array}$ & $\begin{array}{l}\text { Métodos que preconizem a } \\
\text { investigação ativa e } \\
\text { participante, com } \\
\text { estruturação de seminários } \\
\text { para apresentação de } \\
\text { resultados. } \\
\text { Inserção de debates, } \\
\text { trabalhos de pesquisa } \\
\text { coletivo e individual. }\end{array}$ & $\begin{array}{l}\text { Sequência didática, } \\
\text { estruturada com atividades } \\
\text { de pesquisa, reflexão e } \\
\text { contextualização. } \\
\text { Avaliação contínua com } \\
\text { feedbacks para orientar o } \\
\text { andamento dos trabalhos e a } \\
\text { aprendizagem. }\end{array}$ \\
\hline aprála didática \\
\hline
\end{tabular}

Fonte: Diagrama elaborado pela autora.

A proposta didática é formada por passos (Figura 2), porém não devem ser vistos como unidirecionais. Dependendo do contexto da escola podem e devem ser repensados e reorganizados. Caberá ao professor fazer ajustes: os estudantes, a partir do tema gerador, identificam um problema para a pesquisa; deixar claro que levantamento de dados não gera informações; os dados precisam ser tratados e analisados de acordo com a literatura pertinente. A avaliação dos trabalhos é contínua, porém, os estudantes precisam receber ferramentas para fazerem a auto avaliação de suas produções e agregarem os feedbacks do professor, na estruturação das próximas etapas. Em adição, o caráter da avaliação é formativo, contemplando aspectos qualitativos e incluindo as dimensões atitudinais e procedimentais, tais como apontado em Zabala (1998). 


\section{Dialogia}

SANTOS, Telma Temoteo dos. Proposta de sequência didática a partir do filme Os vingadores: guerra

infinita

Figura 2 - Esquema das etapas do desenvolvimento das atividades propostas na sequência didática

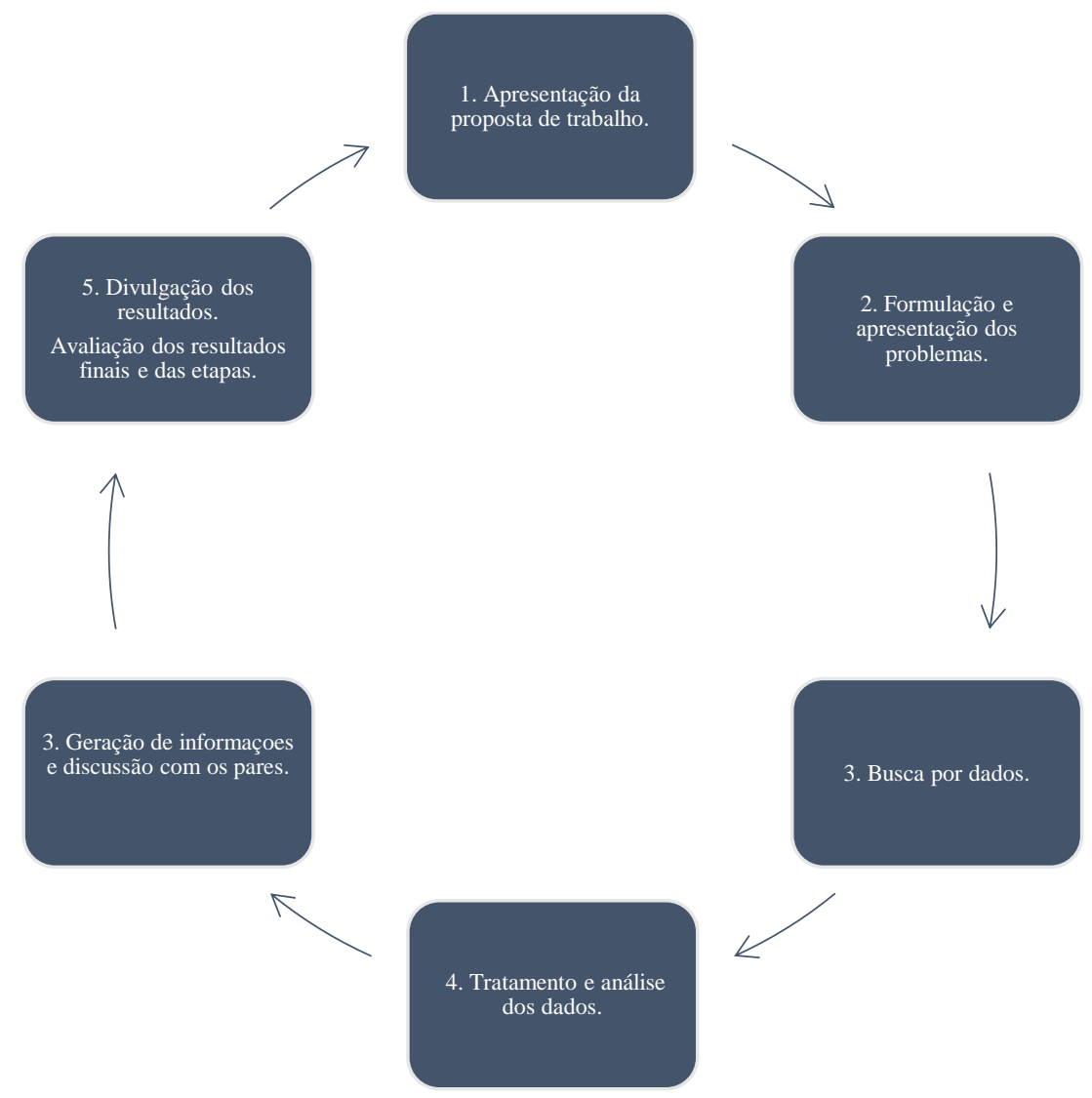

Fonte: Elaborado pela autora.

\section{A sequência didática e seus componentes estruturais}

Na primeira aula, o professor poderá conhecer as impressões dos estudantes sobre o filme, por meio do brainstorming (tempestade de ideias). Desta técnica emergem temas geradores posteriormente organizados em nuvem de palavras, mapas mentais ou conceituais. Estes dados iniciais oriundos de um debate livre podem servir como pontos norteadores para elaboração de atividades que irão compor a sequência didática.

Em seguida, organizar os estudantes em grupos (entre 3 e 4 estudantes). Sugere-se, três tópicos para dar continuidade ao trabalho de investigação e aprendizagem. Outros poderão emergir dos debates em consequência da faixa etária, do aporte sociocultural e das expectativas dos participantes com os temas científicos. Durante a condução das atividades, cada ator social envolvido poderá assumir diversos papeis, como os sinalizados a seguir (POZO; CRESPO, 2009):

- Ações dos estudantes: pesquisar, coletar dados, analisar, problematizar, organizar ideias e debater. 
- Ações do professor: mediar, anotar os pontos das discussões levantados pelos estudantes, orientar, problematizar, propor novas perguntas, analisar e indicar fontes adicionais (se necessário) de pesquisa.

- Ações dos grupos: propor novos pontos de vista para os pontos apresentados pelos demais grupos. Mediação entre professor e grupo para inserção desses pontos e verificação dos desdobramentos que guiarão a pesquisa na etapa seguinte.

Além disso, caberá ao professor não apenas identificar possíveis temas geradores e relacioná-los com conteúdos conceituais, com também incluir:

- Conteúdos procedimentais: estratégias de resolução do problema inicial, capacidade de generalização do conhecimento, das técnicas e do raciocínio.

- Conteúdos atitudinais: mediação de conflitos, exercício da ética e moral, valores, trabalho coletivo, cuidado, tomada de decisão, responsabilidade e comprometimento.

Tópico 1: Verificar se os estudantes conseguiram identificar a ideia central da motivação do Thanos. Neste ponto, espera-se que sejam capazes de percebê-la não apenas em nuances em passagens do filme, mas em falas bem diretas como no diálogo entre as personagens Thanos e Gamora (tempo 1h:06s).

Em complemento, o professor poderá questionar se essa "motivação" com resultados tão perturbadores, já esteve presente na história da humanidade. É de se esperar que os estudantes fiquem surpresos ou ainda possam citar, ainda de forma superficial, os estudos sobre Darwin, mencionando por exemplo, o conceito de seleção natural simplificado a sobrevivência dos "mais fortes", a eliminação dos "mais fracos" (eugenia), ou ainda, ideias associadas ao darwinismo social. Algumas pesquisas mostram como os estudos de Charles Darwin sofreram deturpações de sentido, e usados para embasar políticas de limpeza étnica e racial, e até mesmo em discussões na economia (BOLSANELLO, 1996; BERGO, 1993; STRAUSS; WAIZBORT, 2008). Esses e outros conteúdos conceituais podem ser trabalhados pelo professor, dando destaque aos contextos histórico e sociocultural, como os sugeridos no bloco A, do Quadro 1.

Em seguida, solicitar aos estudantes que organizem os dados trabalhados pelo professor, nas categorias: atores sociais envolvidos, suas descobertas científicas e impactos para a época e atualidade. A História da Ciência será utilizada como uma linha do tempo retrospectiva: a partir do darwinismo social, os estudantes serão encaminhados para os estudos de Darwin e os pontos biológicos, sociais e culturais envolvidos na elaboração da sua Teoria da Evolução. 
Em adição, propor a produção de um texto coletivo com argumentos favoráveis e contrários para as questões levantadas, com posterior socialização das ideias por meio de debate entre os grupos.

Quadro 1 - Proposição de conteúdos conceituais para a sequência didática

\begin{tabular}{|c|c|c|c|c|}
\hline & Bloco A & Bloco B & Bloco C & Bloco D \\
\hline Temas & $\begin{array}{l}\text { Darwinismo } \\
\text { Social. } \\
\\
\text { Teoria } \\
\text { Evolução da } \\
\text { segundo Darwin } \\
\text { (antecessores e } \\
\text { predecessores). }\end{array}$ & $\begin{array}{l}\text { Leis da } \\
\text { Hereditariedade } \\
\text { de Mendel. } \\
\text { Evolução, } \\
\text { descendência } \\
\text { comum, } \\
\text { gradualismo, } \\
\text { multiplicação das } \\
\text { espécies e seleção } \\
\text { natural. }\end{array}$ & Biotecnologia. & Biodiversidade. \\
\hline $\begin{array}{l}\text { Pontos } \\
\text { norteadores }\end{array}$ & $\begin{array}{l}\text { O } \\
\text { desenvolvimento } \\
\text { da teoria da } \\
\text { evolução (História } \\
\text { da Ciência). } \\
\text { Teoria } \\
\text { Malthusiana. }\end{array}$ & 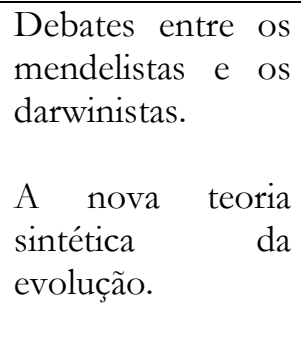 & $\begin{array}{l}\text { Genômica. } \\
\text { Proteomica. } \\
\text { Fertilização in- } \\
\text { vitro. } \\
\text { Terapia gênica. } \\
\text { Clones. } \\
\text { Transgênicos. } \\
\text { Bioética. }\end{array}$ & $\begin{array}{l}\text { Relação parasito } \\
\text { hospedeiro. } \\
\text { Agentes seletivos e } \\
\text { mutagênicos. } \\
\text { Atividades } \\
\text { humanas. }\end{array}$ \\
\hline
\end{tabular}

Fonte: Elaborado pela autora.

Tópico 2: A diversidade das características peculiares de indivíduos é apresentada no filme sob a perspectiva de ter ou não superpoderes, acompanhados da responsabilidade em deter o mal, custe o que custar. Esses "atributos", são provenientes de acidentes biológicos, radioativos, dons mitológicos ou ainda do manuseio dos conhecimentos científicos para fins "duvidosos", condicionando atribuições especiais nas personagens. Partindo desse universo de fantasia e transpondo para a nossa realidade, como podemos explicar a diversidade das características a nível de indivíduo e das populações? Seriam frutos de "acidentes", "eventos direcionados" e "mutações seletivas"?

Os estudantes, talvez, fiquem "presos" às questões evolutivas para explicar a biodiversidade, já que foram pré-desenvolvidas no tópico 1. Por isso, o professor poderá formular perguntas que os tirem de suas zonas de conforto e os aproximem de um conhecimento mais elaborado: os (im)possíveis diálogos entre a Teoria da Evolução de Charles Darwin e os estudos de Gregor Mendel. Darwin, explicou em sua teoria como as características que condicionam melhores condições de vida são passadas de um indivíduo para outro, até se fixarem e Mendel, 


\section{Dialogia}

SANTOS, Telma Temoteo dos. Proposta de sequência didática a partir do filme Os vingadores: guerra infinita

como ocorre essa transmissão (por meio de unidades hereditárias discretas, hoje conhecidos como genes) (BIZZO; EL-HANI, 2009).

Após apresentar os trabalhos de Mendel, com a ervilhas, proponha aos grupos que expliquem a questão 2, pelos pontos de vistas de Darwin e Mendel. Na sequência, solicite aos grupos que adicionem em seus textos os novos pontos levantados no debate coletivo. Indique como sugestão de momento pipoca o vídeo No Jardim de Darwin disponível no canal do Youtube.

E, se tiver oportunidade, lance a seguinte questão: se a transmissão das unidades hereditárias (os genes) é sempre discreta e imutável (como apresentada nos trabalhos de Mendel), de onde vem a diversidade? Como seria possível a ação da seleção natural? Seria a seleção natural a única força evolutiva em ação sobre as populações?

$\mathrm{Na}$ aula seguinte, buscando contextualizar e dar sentido aos temas conceituais, pode-se discutir sobre mecanismos que geram e ampliam a variabilidade genética nos organismos, bem como a relação entre genoma, ambiente e fenótipo, a partir de textos de divulgação científica. $\mathrm{O}$ trabalho interdisciplinar entre genética e evolução (Teoria Sintética da Evolução) auxiliará os estudantes na apreensão de alguns conceitos como: deriva gênica, variação genética, fluxo de genes e especiação. Esses conteúdos podem ser trabalhados por meio de aula expositiva com posterior estudo de caso (Figura 3) no qual os estudantes deverão investigar e integrar os conhecimentos já debatidos anteriormente e apresentar os resultados em um seminário.

Figura 3 - Sugestão de temas para investigação em estudos de casos estruturados pelo professor
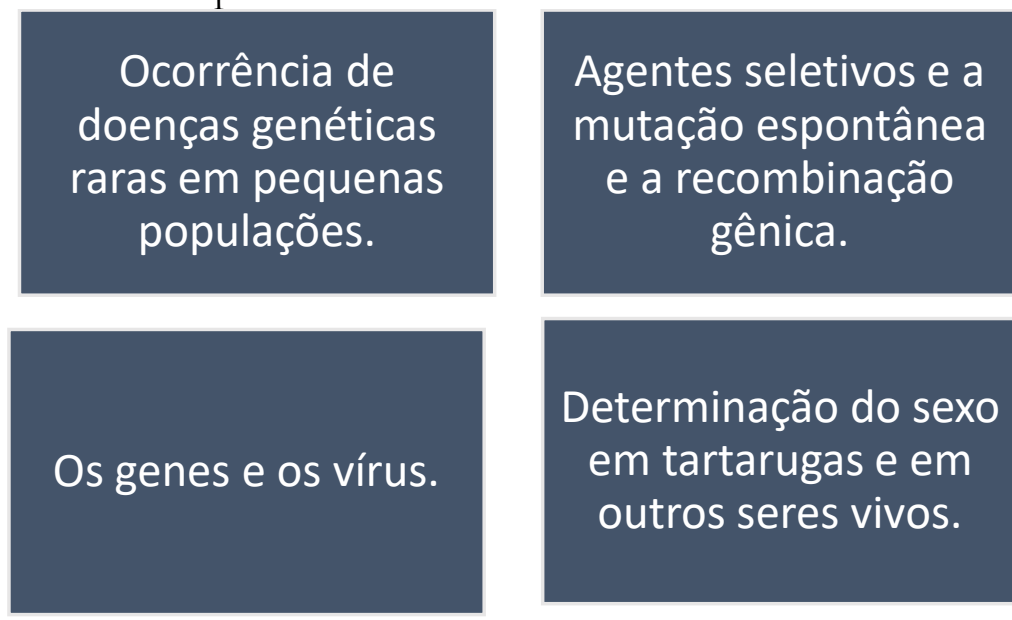

\section{Determinação do sexo}

em tartarugas e em

outros seres vivos.

Fonte: Elaborada pela autora.

Tópico 3: Nos debates anteriores percebemos que a ciência não é elaborada a partir da ótica de apenas um único sujeito, mas resultante da convergência de vários trabalhos, muitas das vezes, inicialmente rejeitados. Assim, pensando na perspectiva da coletividade, da junção de 
saberes, sujeitos e áreas de conhecimento, seria possível a ciência fornecer respostas para a questão que "motiva" o vilão?

Aqui o professor poderá apresentar as limitações dos conhecimentos científicos, já que nos filmes, uma descoberta científica é apresentada como prontamente aplicável, de uso imediato e com poder transformador. Filmes como Gattaca (1997), O enviado (2004), A ilha (2005), apresentaram as expectativas (medos e anseios) do início da era genômica, pois havia diversas representações acerca do tema, que oscilavam de um lado para o início de uma "era de ouro" com os benefícios e as possibilidades imensuráveis do uso de novas técnicas, e do outro lado, o receio da instauração de uma nova ordem mundial, cuja organização da sociedade civil seria ditada pelas informações contidas nos genomas dos seres vivos (GÓES; OLIVEIRA, 2014).

No segundo momento, apresentar como a Biotecnologia, uma área que em parceria com a Genética, Biologia Molecular e Evolução, tem mudado as ações de pesquisa e intervenção para a conservação da biodiversidade, áreas florestais, estrutura de banco de genoma, dentre outras. Por exemplo, a rede Onsa (Organization for Nucleotide Sequencing and Analysis) formada por pesquisadores brasileiros, decodificou o genoma da bactéria Xylella Fastidiosa, que causa a praga do amarelinho em plantações de laranja (MATSUKUMA, 2000; FAPESP, 2000). Essa pesquisa foi crucial para a validação da credibilidade brasileira que se uniu a um consórcio internacional para um dos maiores desafios do final do século XX: o Projeto Genoma Humano (PGH), que conseguiu decodificar todos os genes que fazem parte do genoma da espécie humana.

Nos blocos C e D do Quadro 1 supracitado há sugestões de temas conceituais que podem ser trabalhados a partir do texto da notícia: Projeto liderado por brasileira mapeará genoma de 15 mil pessoas, da Agência Brasil, publicada em 2019

Fechando a sequência didática, o professor poderá orientar seminários a partir da questão: Ao tentar convencer Thanos a não destruir o nosso planeta, quais argumentos (estruturados em projetos) o seu grupo apresentaria? Desafiar os estudantes a incluir pontos levantados durante as atividades e outros novos oriundos de suas investigações.

De modo a ampliar a divulgação dos resultados dos projetos, indica-se, se possível, que os estudantes façam as apresentações com a presença de outras turmas. Poderá se instituir uma comissão de avaliação (com alunos e professores de outras disciplinas), de modo a fomentar as discussões e elaboração dos produtos finais: jogos, podcasts, aplicativos, propostas de intervenção, dentre outros.

Nesta sequência didática não há proposição de tempo para não engessar as possibilidades que porventura podem emergir em diferentes situações pedagógicas. Espera-se que o professor 
esteja atento ao surgimento de outros temas geradores levantados pelos estudantes e, por isso, o roteiro aqui apresentado não se constitui um conjunto de ações engessadas (em tempo ou temas conceituais).

Sugestões de leituras para o professor:

- Evolução, Ciência e Sociedade (FUTUYMA, 2002).

- Genética: da ervilha ao genoma humano (GÓES; AIRES, 2018).

- Darwin na sala de aula: replicação de experimentos históricos para auxiliar a compreensão da teoria evolutiva (SILVA, 2013).

- Registros escritos do conhecimento mútuo entre Gregor Mendel e Charles Darwin. Revista Genética na Escola (BIZZO; SANO; MONTEIRO, 2016).

- O admirável Projeto Genoma Humano (CÔRREA, 2002).

\section{Considerações finais}

É indissociável da elaboração de ações de ensino e aprendizagem considerar os centros de interesse dos estudantes para que esses sujeitos tomem para a si a responsabilidade de sua aprendizagem, ou seja, tornem-se protagonistas. A identificação dos temas geradores é essencial para práticas pedagógicas que contrapõem a educação bancária, entretanto, é uma ação desafiadora e incumbe ao professor a elaboração de planos de ensino alinhados ao currículo, porém interdisciplinares, direcionados para a construção do pensamento complexo, analítico e contextualizado.

O estudante precisa ter a oportunidade de ser apresentado às formas diversas de construção da ciência e da necessidade permanente de revisão dos conceitos científicos, já que na ciência não há verdades absolutas, diferentemente dos dogmas.

$\mathrm{O}$ uso de filmes de fantasia no ensino de ciências e biologia enuncia-se com potencial norteador de atividades estruturantes de uma sequência didática, pautada no ensino dialógico, participativo e de investigação gradual. Nesta atividade apresentada o livro didático da disciplina é posto como material de apoio, de consultas, assim como outras literaturas indicadas, entretanto, não como um plano de aula. Coaduna-se, portanto, com um ensino de ciências atualizado, que acolhe diferentes expectativas e visões de mundo, pois, as possibilidades didáticas superam os limites apresentados nos livros e programas curriculares.

Desta forma, espera-se que a proposição de tópicos, temas de estudos e atividades estruturantes desta sequência fomente outros sujeitos a buscarem a imersão no universo de 


\section{Dialogia}

SANTOS, Telma Temoteo dos. Proposta de sequência didática a partir do filme Os vingadores: guerra infinita

representações e interesses dos estudantes a fim de ofertar uma educação inclusiva e convidativa para a investigação dos temas científicos.

\section{Referências}

BERGO, A. C. Darwinismo social e educação no Brasil. 1993. 260f. Tese (Doutorado em Educação) - Faculdade de Educação, Universidade Estadual de Campinas, Campinas, São Paulo, 1993.

BBC. No Jardim de Darwin. 1 vídeo (57:50). Youtube. Disponível em: https://www.youtube.com/watch?v=qxjhWT0m4Aw. Acesso em: 12 de ago. 2019.

BIZZO, N.; EL-HANI, C.N. O arranjo curricular do ensino de evolução e as relações entre os trabalhos de Charles Darwin e Gregor Mendel. Filosofia e História da Biologia, São Paulo, v. 4, p. 235-257, 2009. Disponível em: http:/ /www.abfhib.org/FHB/FHB-04/FHB-v04-08-NelioBizzo-Charbel-El-Hani.pdf. Acesso em: 10 de mar. 2019.

BIZZO, N. M. V.; SANO, P. T.; MONTEIRO, P. H. N. Registros escritos do conhecimento mútuo entre Gregor Mendel e Charles Darwin: uma proposta para trabalho em sala de aula com história contrafactual da ciência e didática invisível. Genética na Escola, Riberão Preto, v. 11, p. 294 309, 2016. Disponível em: https:/ / 7ced070d-0e5f-43ae-9b1caef006b093c9.filesusr.com/ugd/b703be_13eb5110148b47fdb310bc5593228597.pdf. Acesso em: 15 de out. de 2019.

BOEHM, C. Projeto liderado por brasileira mapeará genoma de 15 mil pessoas. Agência Brasil, São Paulo, 14 dez. 2019. Disponível em: https://agenciabrasil.ebc.com.br/saude/noticia/201912/projeto-liderado-por-brasileira-mapeara-genoma-de-15-mil-pessoas. Acesso em: 02 de mar. 2020.

BOLSANELLO, M.A. Darwinismo social, eugenia e racismo "científico": sua repercussão na sociedade e na educação brasileiras. Educar, Curitiba, n. 12, p. 153-165, 1996. Disponível em: https://www.scielo.br/pdf/er/n12/n12a14.pdf. Acesso em: 16 de outubro de 2019.

CACHAPUZ, A.; GIL-PÉREZ, D.; CARVALHO, A.M.P.; PRAIA, J.; VILCHES, A. A necessária renovação do ensino de ciências. São Paulo: Cortez, 2005. 183 p.

CARVALHO, A.M.P. Ensino de Ciências: unindo a pesquisa e a prática. 2.ed. São Paulo: Cengage Learning, 2016. 154 p.

CARVALHO, A.M.P.; CACHAPUZ, A.F.; GIL-PÉREZ, D. O ensino das ciências como compromisso científico e social: os caminhos que percorremos. São Paulo: Cortez, 2012. $246 \mathrm{p}$.

CASTELLS, M. A sociedade em rede. São Paulo: Paz e Terra, 2017.

CASTILHO, T.B.; OLIVEIRA, J.P.; SALES, N.L.L.; OVIGLI, D.F.B. Filmes de ficção científica na educação em ciências: análise de um minicurso voltada à construção de cine-aulas. In: XI ENCONTRO NACIONAL DE PESQUISAS EM EDUCAÇÃO EM CIÊNCIAS (IX 
SANTOS, Telma Temoteo dos. Proposta de sequência didática a partir do filme Os vingadores: guerra

ENPEC). Anais: [...]. Universidade Federal de Santa Catarina (SC), julho 2017. Disponível em: http://www.abrapecnet.org.br/enpec/xi-enpec/anais/resumos/R1310-1.pdf. Acesso em: 12 de ago. 2019;

CÔRREA, M.V. O admirável Projeto Genoma Humano. Physis: Revista Saúde Coletiva, Rio de Janeiro, v.12, n. 2, p. 277-299, 2002. Disponível em: https://www.scielo.br/pdf/physis/v12n2/a06v12n2. Acesso em: 12 de ago. 2019.

DELIZOICOV, D.; ANGOTTI, J.A.; PERNAMBUCO, M.M. Ensino de Ciências: fundamentos e métodos. São Paulo: Cortez 2018. 285 p.

DEMO, P. Saber pensar. São Paulo: Cortez, Instituto Paulo Freire, 2002. 159 p.

FAPESP. Xylella: concluído o genoma da bactéria. 2000. São Paulo, ed. 50. Disponível em: https://revistapesquisa.fapesp.br/xylella-concluido-o-genoma-da-bacteria/. Acesso em: 13 de fev. 2020.

FREIRE, P. Conscientização: teoria e prática da libertação. São Paulo: Cortez \& Moraez, 1979. $53 \mathrm{p}$.

FREIRE, P. Pedagogia da autonomia. São Paulo: Editora Paz e Terra, 2011. 60 p.

FUTUYMA, D.J. Evolução, Ciência e Sociedade. Sociedade Brasileira de Genética. 2002. Ebook. 73 p. Disponível em:

https://www.sbg.org.br/sites/default/files/evolucao_ciencia_e_sociedade.pdf. Acesso em: 17 de fev. 2020.

GÓES, A.; AIRES, R. Genética das ervilhas ao genoma humano. Sociedade Brasileira de Genética. 2018. E-book. 233 p. Disponível em:

https://www.sbg.org.br/sites/default/files/genetica_ervilhas.pdf. Acesso em: 17 de fev. 2020.

GÓES, A.C.S.; OLIVEIRA, B.V.X. Projeto Genoma Humano: um retrato da construção do conhecimento científico sob a ótica da revista Ciência Hoje. Ciência e Educação, Bauru, v. 20, n. 3, p. 561-577, 2014. DOI: http://dx.doi.org/10.1590/1516-73132014000300004. Disponível em: https://www.scielo.br/pdf/ciedu/v20n3/1516-7313-ciedu-20-03-0561.pdf. Acesso em: 20 de jul. 2019.

HARRES, M.C.G; SOUZA, A.R. A ficção científica e o ensino de ciências: o imaginário como formador do real e do racional. Ciência e Educação, Bauru, v.14, n.2, p. 271-282, 2008. DOI https:// doi.org/10.1590/S1516-73132008000200006. Disponível em: https://www.scielo.br/pdf/ciedu/v14n2/a06v14n2.pdf. Acesso em: 20 de jul. 2019.

HARRES, J.B.S. Natureza das Ciências e as implicações para a educação científica. In: MORAES, R. Construtivismo e ensino de ciências: reflexões epistemológicas e metodológicas. Porto Alegre: EDIPUCRS, 2000. p. 37-68.

LIBÂNEO, J.C.; OLIVEIRA, J.F.; TOSCHI, M.S. Educação Escolar: políticas, estrutura e organização. São Paulo: Cortez, 2012. 543 p. 
LÜDKE, M.; ANDRÉ, M. E. D. A. Pesquisa em educação: abordagens qualitativas. 2. Ed. São Paulo: Epu, 2013. 128 p.

MARTINS, R.A. Introdução. A história das ciências e seus usos na educação. In: SILVA, C.C. Estudos de história e filosofia das ciências: subsídios para aplicação no ensino. São Paulo: Livraria da Física, 2006. Introdução. p. xxi- xxxiv.

MATSUKUMA, A.Y. Sequenciamento e anotações de parte do genoma da Xylella fastidiosa. 2000. 159 p. Dissertação (Mestrado em Bioquímica) - Instituto de Química, Universidade de São Paulo, São Paulo, 2000. DOI 10.11606/D.46.2001.tde-06022009-160615. Disponível em: https://teses.usp.br/teses/disponiveis/46/46131/tde-06022009-160615/ptbr.php. Acesso em: 20 de jul. 2019.

PENAFRIA, M. Análise de Filmes - conceitos e metodologia(s). In: VI CONGRESSO SOPCOM, Universidade Lusófona de Humanidades e Tecnologia, Lisboa, 2009. Disponível em: http://www.bocc.ubi.pt/pag/bocc-penafria-analise.pdf. Acesso em: 12 de jul. de 2019.

PIASSI, L.P.; PIETROCOLA, M. Ficção científica e ensino de ciências: para além do método de encontrar erros em filmes. Educação e Pesquisa, São Paulo, v. 35, n. 3, p. 525-542, 2009.

Disponível em: https://www.scielo.br/pdf/ep/v35n3/08.pdf. Acesso em: 20 de jul. 2019.

POZO, J.I.; CRESPO, M.A.G. A aprendizagem e o ensino de ciências: do conhecimento cotidiano ao conhecimento científico. Porto Alegre: Artmed, 2009. 294 p.

SILVA, T.T. Darwin na sala de aula: replicação de experimentos históricos para auxiliar na compreensão da teoria evolutiva. 2013. 172 folhas. Dissertação (Mestrado em Ensino de Biologia), Interunidades em Ensino de Ciências, Universidade de São Paulo, São Paulo, 2013. DOI 10.11606/D.81.2013.tde-25072014-173516. Disponível em:

https:/ /www.teses.usp.br/teses/disponiveis/81/81133/tde-25072014-173516/pt-br.php. Acesso em: 12 de ago. 2019.

SIQUEIRA, P. B. Análise fílmica da animação "osmose jones" e sua utilização como material complementar no ensino de ciências e biologia. 2017. 39 folhas. Trabalho de conclusão de curso (Licenciatura em Ciências Biológicas). Instituto de Ciências Biológicas e da Saúde da Universidade Federal Rural do Rio de Janeiro, Seropédica, Rio de Janeiro, 2017. Disponível em: http:/ / repositorio.im.ufrrj.br:8080/jspui/handle/1235813/2912. Acesso em 12 de jul. 2019.

STRAUSS, A.; WAIZBORT, R. Sob o signo de Darwin? Sobre o mau uso de uma quimera. Revista Brasileira de Ciências Sociais, v. 23, n. 68, São Paulo, 2008. Disponível em: https://doi.org/10.1590/S0102-69092008000300009. Acesso em: 12 de ago. 2019.

ZABALA, A. A prática educativa: como ensinar. Porto Alegre: Artmed, 1998. 224 p.

Recebido em: 31 ago. 2020/ Aprovado em: 27 nov. 2020

Cite como 


\section{Dialogia}

SANTOS, Telma Temoteo dos. Proposta de sequência didática a partir do filme Os vingadores: guerra

(ABNT NBR 6023:2018)

SANTOS, Telma Temoteo dos. Proposta de sequência didática a partir do filme Os vingadores: guerra infinita. Dialogia, São Paulo, n. 36, p. 550-567, set./dez. 2020. Disponível em: https://doi.org/10.5585/dialogia.n36.18051.

\section{American Psychological Association (APA)}

SANTOS, T. T. (2020, set./dez.).Proposta de sequência didática a partir do filme Os vingadores: guerra infinita. . Dialogia, São Paulo, 36, p. 550-567:

https://doi.org/10.5585/dialogia.n36.18051. 